\title{
DISCLOSURE OF INTANGIBLE ASSETS IN BRAZIL AND AUSTRALIA UNDER THE PER- SPECTIVE OF THE THEORY OF THE CULTURAL RELEVANCE OF ACCOUNTING ${ }^{1}$
}

\author{
Evelini Lauri Morri Garcia ${ }^{2}$ \\ PhD Student in Management at State University of Maringá \\ evelinilaurimorri@hotmail.com \\ orcid.org/0000-0003-4321-8643 \\ Leonardo Pestana Legori \\ Bachelor degree in Accounting by State University of Maringá \\ leonardopl@outlook.com \\ orcid.org/0000-0002-4169-2336 \\ Simone Leticia Raimundini Sanches \\ $\mathrm{PhD}$ in Management by Federal University of Rio Grande do Sul \\ Professor at State University of Maringá \\ slraimundini@uem.br \\ orcid.org/0000-0002-7363-2573 \\ Valter da Silva Faia \\ PhD Student in Management at State University of Maringá \\ valterfaia@gmail.com \\ orcid.org/0000-0002-9320-1885
}

\begin{abstract}
Objective: To evaluate the differences in the disclosure practices of intangible assets, according to IFRS specifications, in Brazilian and Australian companies.

Rationale: Intangible assets have relative subjectivity that makes it difficult to estimate their future economic benefits. Despite the requirement to disclose this information, there is low adherence to CPC 04, which can be investigated by comparing the Brazilian dissemination with culturally distinct countries, such as Australia. This perspective is supported by the Theory of Cultural Relevance in Accounting, proposed by Gray (1988).

Method: The sample consists of 6 companies listed on the BM\&FBovespa and 10 companies of the Australian Securities Exchange, belonging to the Information Technology sector, subsector of Programs and Services. The level of disclosure of intangible assets was identified by analyzing the content of the financial statements for the year 2015, based on the requirements of IAS 38. The difference in means was made by the Mann-Whitney U test.
\end{abstract}

\footnotetext{
${ }^{1} 1$ Article received on: 08/10/2017. Peer reviewed on: 10/21/2017. Reformulated on: 10/27/2017. Recommended for publication in: 10/27/2017 by Adriana Fernandes de Vasconcelos (Editor). Published: 11/02/2017.

Organization responsible for the periodical: UFPB.

${ }^{2}$ Address: Av. Colombo, 5790 - Zona 7, Maringá - PR, 87020-900.

DOI: http://dx.doi.org/10.18405/recfin201801011
} 
Results: The average level of disclosure of intangible assets of Australian companies was 52.73\% and Brazilian companies was $43.18 \%$. This result meets the expectation of greater disclosure by Australian companies, supported by Gray's Theory of Cultural Relevance of Accounting (1988). However, the assumption that Australia's culture influences high transparency has not been verified.

Contributions: It discusses the understanding of the accounting exercise from local behavioral precepts, expanding empirical notions based on Cultural Relevance, a theoretical approach that is not much debated. It raises questions about the position of the Brazilian bodies that issue accounting standards on the actions employed in order to adapt the Brazilian trends stemming from the culture to IFRS compliance.

Keywords: Intangible Assets. Disclosure. Culture.

\section{INTRODUCTION}

In postmodern economics, knowledge is the main element that makes up the value of a business (Avelino, Pinheiro \& Lamounier, 2012, Oliveira \& Lemes, 2011). In companies in the technology area, intangible assets represent intrinsic elements of their operations and directly interfere in the results of these entities (Colauto, Nascimento, Avelino \& Bispo, 2009). However, intangible assets constitute one of the most complex areas of accounting theory in view of uncertainties and subjectivity in the measurement of its values and determination of useful life, which consequently interferes with the ability to estimate future economic benefits (Belém \& Marques, 2012, Crisóstomo, 2009, Moura, Dallabona, Fank \& Varela, 2013).

In order to establish limits on the subjectivity of intangible assets, the International Accounting Standard (IAS) 38 was issued, developed by the International Accounting Standards Board (IASB) in 1998. In Brazil, the adoption of the International Financial Reporting Standards (IFRS) occurred in 2010 due to the movement of international accounting harmonization. From the convergence process, Brazilian companies must disclose their intangible assets in compliance with Technical Pronouncement 04 - Intangible Assets, issued by the Accounting Pronouncements Committee (CPC), correlated to IAS 38.

Researches on the disclosure of intangible assets in Brazil show that, in general, the companies do not adequately comply with the mandatory disclosure determined by IFRS (Mopes, Alves, Silva Filho, Monteiro, Lagioia, \& Cordeiro, 2014, Klann, Popik, Kreuzberg \& Salla, 2014, Meneses, Ponte \& Mapurunga, 2013, Moura et al., 2013). As a justification, the culture emerges as a possible restrictive factor to the compliance with current accounting standards by Brazilian companies (Kushniroff, 2012, Lima, 2016, Meneses et al., 2013, Souza, 2009).

Based on this context, it is possible to deepen the understanding about the phenomenon of low adherence to CPC 04, under the aspect of disclosure, comparing the Brazilian disclosure with countries that have opposite characteristics (Chrysostom, 2009, Souza, 2009). Australia is one of those cases, whose adoption of IFRSs is older and mandatory as of 2005 through the Australian Accounting Standards Board (AASB) 138, adapted from IAS 38. In addition, the culture of companies in this country, of Anglo-Saxon origin, is distinct from Brazilian companies (Souza, 2009). This perspective is supported by the Theory of Cultural Relevance of Accounting, proposed by Gray (1988), which relates the culture of each country to the respective accounting practices. This scenario, therefore, raises the following question: What is the difference in the disclosure practices of intangible assets, in the light of international accounting standards, of Brazilian and Australian companies?

In order to elucidate this question, the study aims to evaluate differences in the disclosure practices of intangible assets, according to IFRS specifications, in Brazilian and Australian companies. To this end, the field of analysis focuses on information technology companies listed on the 
BM\&FBovespa and the Australian Securities Exchange, whose segment represents a significant proportion of intangibles in its fixed assets, as well as implies relevance in the operational activities of these entities (Moura et al., 2013).

This is a timely study, since surveys that consider the accounting reality in different countries identify the possible influence of the local culture (Gray, 1988). Thus, it is possible to evaluate how accounting standards are met by agents of different nationalities and whether different financial markets are being supported by information in accordance with IFRSs (Lima, 2016, Meneses et al., 2013). In addition, it is possible to verify whether the length of time between the period of adoption of IFRS and the most current practice of such standards can be treated as an element that raises expectations of improvement in the disclosure of information (Klann et al., 2014, Lopes et al., 2014, Moura et al., 2013).

The interpellation of possible divergences in adherence to IAS 38 in Brazil and Australia provides a basis for understanding adherence to IFRS and to develop the estimation of future scenarios regarding the availability of accounting information (Dantas, Zendersky, Santos \& Niyama, 2005, Klann et al., 2014, Oliveira \& Lemes, 2011), especially in the information technology sector, which has a central position in the economic scenario (Colauto et al., 2009). It also raises questions about the issuance of standards by confronting the global standardization of accounting practices with the particular behavior of specific social systems (Gray, 1988, Kushniroff, 2012). The present research also contributes to the development of the Theory of Cultural Relevance of Accounting, which is supported predominantly by strictly theoretical principles that demand empirical analysis in order to improve its scientific usefulness.

\section{THEORETICAL FOUNDATION}

In this chapter, we discuss the disclosure of intangible assets under the approach of accounting standards and previous research on the subject. This analysis is complemented by the presentation of Cultural Theory of Relevance in Accounting.

\subsection{Disclosure of Intangible Assets According to the International Accounting Standards}

The disclosure can be understood as the process of opening the company for the disclosure of information, so that the user can obtain information about the financial condition of the company (Avelino et al., 2012, Klann et al., 2014, Meneses et al., 2013, Moura et al., 2013). However, the disclosure must be carried out with quality, timeliness, and clarity (Dantas et al., 2005).

The total disclosure set should contain information regulated by accounting standards and other information useful to stakeholders (Colauto et al., 2009). Therefore, disclosure may be compulsory, covering information legally required by regulatory and class or voluntary bodies, which involves information that is not required by law but provides greater transparency of the company's economic situation (Klann et al., 2014, Meneses et al., 2013).

Regarding the compulsory context of accounting standards, Oliveira and Lemes $(2011,158)$ point out that "[...] the adoption of a common international language is capable of producing concrete benefits when decision-making by these users". As a result, the accounting convergence process aims to integrate accounting practices among countries to meet the global information needs (Colauto et al., 2009, Oliveira \& Lemes, 2011).

According to the Instruction CVM no 457/2007, Brazilian publicly-traded companies presented their statements according to international standards as of the year ended in 2010. In Australia, the adoption of IFRS was mandatory as of the year beginning in 2005. The AASB was charged with issuing the Australian pronouncements that correlate with IFRSs (Gallery, Cooper \& Sweeting, 2008). 
In regard to the standardization of intangible assets, the IASB issued the International Accounting Standard (IAS) 38, establishing recognition, measurement and disclosure criteria. In Brazil, IAS 38 was adopted through Technical Pronouncement CPC 04 - Intangible Assets. In Australia, IAS 38 was adapted by the AASB, which issued accounting standard AASB 138, correlating with the international standard.

Although the study of intangible assets is not something new, there is a growing interest in both the academic and the business environment (Avelino et al., 2012). This reflects the combination of increased competition between firms and the development of information technology (Klann, et al., 2014).

Among the researches that investigated the disclosure of intangible assets, there is Chrysostom (2009), which evaluated how Brazilian legislation treats intangible assets by comparing this situation with other accounting systems in the pre-convergence period. It found that despite the recent advances obtained with the enactment of Law 11.638 / 2007, it was only with the publication of CPC 04 in 2008 that a better formalization of the treatment of intangible assets was obtained. In addition, it indicated that several companies registered on the BOVESPA had already recognized and disclosure intangible assets in their balance sheets since 2005, following CVM Resolution 488/2005. It also reported that many countries already had their own regulations on intangible assets, even before the issuance of IFRS. Australia is one of these cases, while Brazil only started to hold regulations on this asset from the process of convergence with international standards.

Avelino et al. (2012) studied the disclosure index of compulsory information on intangible assets of 47 companies listed in the theoretical portfolio of Ibovespa, related to the financial year of 2010. The results showed that the average rate of compliance with the normative criteria was $70.21 \%$ and that Copel presented the highest level of disclosure of intangible assets (88\%). None of the companies analyzed by this research fully complied with the determinations of CPC 04 (R1).

Klann et al. (2014) verified the factors that influence the level of disclosure of information on intangible assets in companies listed in the BM\&FBovespa Corporate Governance Index (IGC) in the period after the adoption of the International Financial Reporting Standards (IFRS). It was identified that in 2011 the average mandatory disclosure index for intangible assets was $51.37 \%$ and that the sectors investing more in information technology are likely to disclose more information quantitatively.

The study by Lopes et al. (2014) had the objective of verifying the level of adherence of publicly traded companies in the industrial goods sector to the disclosure items of CPC 04 (R1) since its applicability in 2008 until the year ended in 2011. The study concluded that, on average, only $6.71 \%$ of the companies did not disclose information about their intangible assets in their explanatory notes and that, on average, during the four years of analysis, the reported information compliance index was $61.94 \%$ with a tendency to grow over time. In addition, none of the companies studied disclosure all mandatory items.

According to the results of the mentioned studies, it is observed that the information on intangible assets disclosure by Brazilian companies do not present complete compliance with the mandatory disclosure items, as specified by international standards. However, according to Klann et al. (2014), the sectors that invest more in information technology disclose more information on intangibles.

With regard to Australian companies, Gallery et al. (2008) examined the quality of disclosure presented by Australian companies regarding the impact on the financial statements arising from the adoption of the Australian Equivalents of International Financial Reporting Standards (AIFRS). The survey sampled the 408 largest Australian companies, whose annual financial statements for 2005 were analyzed to identify the quality of the disclosure in accordance with AASB 1047, a standard that aims to provide users of financial reporting with information on the impacts of changes in 
accounting practices resulting from the implementation of Australian standards equivalent to IFRS. The average disclosure quality score obtained by the companies was 8 points, with approximately $47 \%$ of the total of the maximum possible score (17 points). Therefore, it is possible to understand that the Australian companies did not present complete disclosure or near its completeness in the year of adoption of the international norms.

No recent research on the disclosure of intangibles in Australian companies was found. In addition, no study specifically addresses the disclosure of intangibles in a comparative manner between Brazilian and Australian companies. This gap in the literature supports the objective of the present study. In order to answer it, it is necessary to seek theoretical bases that support the empirical analysis.

\subsection{Theory of the cultural relevance of accounting}

The Theory of Cultural Relevance of Accounting was developed Gray (1988) and is an unfolding of the study of Hofstede (1980), which identified four cultural dimensions that affect the actions of individuals belonging to a social group. Gray (1988) made an adaptation of this study indicating the existence of the relationship between cultures, social values and accounting systems (Lima, 2016).

Culture is defined as the collective programming of the mind that distinguishes the members of a human group from another group (Hofstede, 1980). The word "culture" is reserved for societies as a whole, or for nations, while "subculture" is used for the hierarchy of an organization, profession or family (Gray, 1988).

The Theory of Cultural Relevance is structured by Gray (1988) with four accounting values considered subcultural aspects of Accounting, which are (i) professionalism versus legal control, (ii) uniformity versus flexibility, (iii) conservatism versus optimism and (iv) secrecy versus transparency.

The first value relates the dichotomy between professional judgment and respect for professional regulation and compliance with legal and statutory requirements. The second aspect indicates the tendency of a uniform performance in the use of accounting policies and the consistency over time, in contrast to the flexibility that can meet specific situations of each entity. This aspect is related to comparability between companies. Conservatism versus optimism establishes a preference for caution in the face of uncertainty, being opposed to optimism and risky reasoning. And, finally, secrecy versus transparency indicates the trend of restriction in the disclosure of information about the business, contrary to full disclosure. This book value is related to conservatism, involving prudence in accounting disclosure (Gray, 1988).

In addition to identifying the pillars of the Theory of Cultural Relevance, Gray (1988) makes a categorization of the accounting culture of several countries also using as basis the research of Hostede (1980). In this classification, Brazil is ranked among the most developed Latin countries, while Australia belongs to the group of countries of Anglo-Saxon culture.

As for the accounting systems that deal with authority and execution, related to aspects (i) and (ii) of the theory, Brazil and Australia are indicated by Gray (1988) as countries with different characteristics. Brazil is considered a country whose accounting practices tend to be more professional than to legal assistance. However, the level of professionalism is considered low. Australia also tends more towards professionalism than legal assistance, however, unlike Brazil, is considered a country with a high level of professional attitudes on the part of the accounting. From the perspective of the second book value, Brazil and Australia occupy opposite levels, because Brazil is considered a country with a high level of uniformity, while Australia is a country with a high level of flexibility. 
In relation to accounting systems that address measurement and disclosure, correlated to values (iii) and (iv) of the theory, Brazil and Australia are also classified in opposite situations. Brazil is ranked among the countries that tend to have a high level of conservatism and a moderate tendency of secrecy, while Australia belongs to the group of countries with a high degree of optimism and transparency (Gray, 1988).

This classification shows that the Brazilian and Australian accounting are surrounded by different cultural values and that this can lead to different information contexts, even though the same international norms are bound (Chrysostom, 2009). It is widespread the idea that the bodies responsible for overseeing the application of IFRS in Australia can achieve greater success in their missions compared to the Brazilian case, because it has experience in working with principles-based accounting (Souza, 2009). In addition, there is an expectation that the level of disclosure of Brazilian companies will be lower in relation to companies of Anglo-Saxon origin (Lima, 2016). However, even if countries are involved in specific cultures, the international standardization of accounting should not be understood as an unattainable situation. According to Kushniroff (2012), accounting convergence should consider local culture and have flexibility in how to apply standards in each country to succeed.

Research published under these perspectives indicates cultural and behavioral characteristics as influencing the adherence to IFRS by Australians. Based on the assumptions made by Gray (1988), who analyzed the relationship between cultural characteristics and accounting practices, as well as subcultural components that affect accounting systems, Kushniroff (2012) found that Australians are less likely to abide by their authorities, behavior explained by high individualism. They also have a high level of conservatism, which indicates that accountants are less likely to manage results. Finally, due to the low level of secrecy, Australian accountants tend to disclose accounting and financial information.

According to Kushniroff (2012), Australian accountants make decisions based on their own personal ethics, not considering what others will think of their actions. Therefore, they are less likely to consider the status of their clients when making decisions and making judgments about accounting performance. According to Kushniroff (2012), Australians tend to assess benefits and losses when making a decision involving ethics.

With regard to Brazil, Lima (2016) verified to what extent the cultural dimensions impact the accounting practice. This research indicated that the accounting operators are, mainly, conservatives and the cultural dimensions that most impact the accounting practice are the aversion to uncertainty and the distance from power. It was concluded that it is not possible to infer that, at first, the adoption of international accounting standards provides an improvement in the accounting process, since the countries where these rules were originally conceived (legal tradition of the common law) present a low aversion to the uncertainty and the distance of the power, something contrary to what was found in that investigation.

Souza (2009), based on the model elaborated by Gray (1988), observes that Brazil presents an opposite tendency to that of the Anglo culture group, which Australia is a part. This is because Brazilians show preference for greater uniformity and conservatism and lower levels of transparency and professionalism, which may constitute a barrier to the adoption of IFRS. In other words, countries with a high degree of conservatism tend to postpone the recognition of assets and profit-increasing items, while high secrecy results in a tendency to reduce the disclosure of relevant information to users.

Souza (2009), based on the model elaborated by Gray (1988), observes that Brazil has a tendency opposite to that of the Anglo culture group, which Australia is a part of. Because Brazilians show a preference for greater uniformity and conservatism and levels of transparency and professionalism, which may constitute a barrier to the adoption of IFRS. In other words, countries with a 
high degree of conservatism tend to postpone the recognition of assets and profit-increasing items, while high secrecy results in a tendency to reduce the disclosure of relevant information to users.

The comparison between Brazilian and Australian companies regarding compliance with IFRS was carried out by Costa, Correia, Machado \& Lucena (2016) from the perspective of the Theory of Cultural Relevance of Accounting. In this research, we analyzed the disclosure of contingent liabilities of companies in the Brazilian market and the Australian market during the period from 2010 to 2015. It was verified that the companies present a still timid adherence ( $23 \%$ by the Brazilian companies and $28 \%$ by the Australian companies), but, both Brazilian and Australian cases, the level of disclosure remained constant during the analyzed period. Particular properties of each country were also observed in relation to their contingencies. Also, it is highlighted that firms, even though they are from the same sectors, may present different characteristics of contingent liabilities, because of the cultural differentiation advocated by Gray (1988), when applying the IFRS. The study demonstrates, therefore, that the cultural differentiation between Brazil and Australia is a relevant factor in the way accounting is developed in each country.

\section{METHODOLOGICAL PROCEDURE}

The research characterizes its objectives as descriptive, since it aims to evaluate differences in disclosure practices of intangible assets, in accordance with IFRS, in Brazilian and Australian companies. According to Silva (2010), the descriptive research describes the characteristics of a particular population or phenomenon.

The study population comprises companies that presented financial statements for the accounting year ended in 2015, belonging to the Information Technology sector, subsector of Programs and Services listed on the BM\&FBovespa and companies belonging to the Information Technology sector, Software \& Services subsector listed on the Australian Securities Exchange (ASX). The choice of analyzing companies solely from a subsector is motivated by standardizing the sample. Considering only companies engaged in related activities, it is expected that other factors influencing the results of the study will be minimized. Thus, when investigating only the subsector of Programs and Services, it is sought to highlight the relevance that intangibles assume in this segment.

The sample is intentional and non-probabilistic, comprising the ten largest companies in the subsector Programs and Services of each stock exchange, whose selection criterion was the market value of companies that have intangible assets in their balance sheets in August 2016. When searching for such information, only 6 Brazilian companies were found, due to the fact that this is the total number of companies listed on BM\&FBovespa, considering the delimitations of the research. Therefore, the sample was composed by the Brazilian companies Idei-asnet S.A., Linx S.A., Quality Software S.A, Senior Solution S.A., Telec Brasileiras S.A. Telebras and Totvs S.A. The Australian companies in the sample were Aconex Limited, Carsales.com Limited, Computershare Limited, Hansen Technologies Limited, Iress Limited, Link Administration Holdings Limited, Myob Group Limited, Myob Group Limited, Nextdc Limited, Technology One Limited and Xero Limited NZX.

The data related to the compulsory disclosure of intangible assets were obtained through the financial statements of the companies that make up the sample, in particular the balance sheet and explanatory notes. To this end, a checklist was elaborated, shown in Table 1, based on the disclosure requirements of IAS 38. Thus, we can define the study as a documentary research, because documents are used as sources of data, information, and disclosure (Martins \& Theóphilo, 2009).

Table 1 - Compulsory Disclosure Indicated in IAS 38

\begin{tabular}{|c|c|l|}
\hline \multicolumn{2}{|c|}{ Items IAS 38 } & \multicolumn{1}{c|}{ Items IAS 38 Description of the information to be disclosed } \\
\hline 1 & 118 & Disclosure of asset classes \\
\hline 2 & 118 & Distinction between internally and externally generated assets and other intangible assets \\
\hline 3 & $118(\mathrm{a})$ & Useful life, Shelf life, or amortization rates used \\
\hline
\end{tabular}




\begin{tabular}{|c|c|c|}
\hline 4 & $118(\mathrm{~b})$ & Amortization methods used for intangible assets with a defined useful life \\
\hline 5 & 118 (c) & $\begin{array}{l}\text { Gross book value and accumulated amortization (plus accumulated losses on the recoverable value) } \\
\text { at the beginning and at the end of the period }\end{array}$ \\
\hline 6 & $118(\mathrm{~d})$ & Income statement caption in which any amortization of intangible assets is included \\
\hline & $118(\mathrm{e})$ & Reconciliation of book value at the beginning and end of the period, for example: \\
\hline 7 & 118 (e) (i) & $\begin{array}{l}\text { Additions, separately indicating those generated by internal and acquired development, as well as } \\
\text { those acquired through a business combination }\end{array}$ \\
\hline 8 & 118 (e) (ii) & Assets classified as held for sale or included in a group of assets classified as held for sale \\
\hline 9 & 118 (e) (iii) & $\begin{array}{l}\text { Increases or reductions during the period, arising from revaluations and loss for recognized asset de- } \\
\text { valuation or reverted directly to shareholders' equity }\end{array}$ \\
\hline 10 & 118 (e) (iv) & Provisions for losses of assets, recognized in the period result \\
\hline 11 & $118(\mathrm{e})(\mathrm{v})$ & 1 of loss due to devaluation of assets, \\
\hline 12 & $118(\mathrm{e})(\mathrm{vi})$ & Any amortization recognized in the period \\
\hline 13 & 118 (e) (vii) & $\begin{array}{l}\text { Net exchange rate variations generated by the translation of the financial statements into the presen- } \\
\text { tation currency and foreign operations into the presentation currency of the entity }\end{array}$ \\
\hline 14 & 118 (e) (viii) & Other changes in book value during the period \\
\hline 15 & 120 & Information on intangible assets that have lost their value \\
\hline 16 & 121 & $\begin{array}{l}\text { Nature and value of changes in accounting estimates that have a relevant impact in the current pe- } \\
\text { riod or in subsequent periods }\end{array}$ \\
\hline 17 & 122 (a) & $\begin{array}{l}\text { Book value of intangible assets evaluated with an indefinite useful life and the reasons for this evalu- } \\
\text { ation }\end{array}$ \\
\hline 18 & $122(b)$ & $\begin{array}{l}\text { Description, book value and remaining amortization period of any individual intangible asset rele- } \\
\text { vant to the entity's financial statements }\end{array}$ \\
\hline 19 & $122(\mathrm{c})$ & $\begin{array}{l}\text { Fair value, book value, and method of measurement of intangible assets acquired through govern- } \\
\text { ment subsidy or assistance and initially recognized at fair value }\end{array}$ \\
\hline 20 & $122(\mathrm{~d})$ & $\begin{array}{l}\text { Existence and carrying amounts of intangible assets whose ownership is restricted and book values } \\
\text { of intangible assets offered as collateral for obligations }\end{array}$ \\
\hline 21 & $122(\mathrm{e})$ & Value of contractual commitments arising from the acquisition of intangible assets \\
\hline 22 & 126 & Total number of researches spending and development known as expenses in the period \\
\hline
\end{tabular}

Source: Adapted from IASB (2013)

Among the disclosures indicated by IAS 38, items 7 through 14 of the checklist differ with AASB 138, which specifies that entities that adopt the Australian Accounting Standards - Reduced Disclosure Requirements do not need to submit reconciliation information with prior periods, although it is still necessary to present reconciliation information for the current period. It is also noted that, although the mandatory disclosure information contained in CPC 04 (R1) does not differ from those in IAS 38, the revaluation of tangible or intangible assets in Brazil is not permitted due to provisions contained in Law 11638/07, that changed the law 6404/76, effective as of January 1, 2008. Therefore, these particularities were considered when analyzing the criteria that are required in each country.

We used the technique of content analysis that, according to Martins and Theóphilo (2009, p. 99) "[...] seeks the essence of a text in the details of the information, given the available evidence." In order to identify the different types of intangible assets, categorization was employed, which, according to Bardin (1977), is based on sorting operations and grouping of text into categories. Thus, four categories were elaborated (Table 2), being assigned to each category of analysis a score according to the level of disclosure of the information.

Table 2 - Category of the information analysis

\begin{tabular}{|c|l|c|}
\hline $\begin{array}{l}\text { Category of the in- } \\
\text { formation analysis }\end{array}$ & \multicolumn{1}{|c|}{ Description } & Scores awarded \\
\hline 1 & $\begin{array}{l}\text { It does not disclose mandatory criteria and does not notify the reason } \\
\text { for such absence. }\end{array}$ & 0 \\
\hline
\end{tabular}




\begin{tabular}{|c|l|c|}
\hline 2 & $\begin{array}{l}\text { Discloses that meets the criteria required by the standardization, with- } \\
\text { out any quantitative or qualitative assessment. }\end{array}$ & 1 \\
\hline 3 & $\begin{array}{l}\text { It discloses the criterion required by the standardization only quantita- } \\
\text { tively or only qualitatively when the disclosure of the two aspects are } \\
\text { required; or, } \\
\text { Partially discloses the criteria. }\end{array}$ & 2 \\
\hline 4 & $\begin{array}{l}\text { It discloses the criteria required by the regulations in quantitative and } \\
\text { qualitative form (when applicable); or, } \\
\text { It does not disclose mandatory criteria, however, it communicates the } \\
\text { non-application of this obligation and the reason for such absence. }\end{array}$ & 3 \\
\hline
\end{tabular}

Sources: Own elaboration

Considering that the research accomplishes identification of the disclosure related to the intangible assets comparing the results between Brazil and Australia through the Mann-Whitney nonparametric $U$ test, the research is classified, as regards the approach, as qualitative and quantitative. According to Beuren, Longaray, Raupp, Sousa, Colauto \& Porton (2006), the qualitative researches allow to carry out deep analyzes of the phenomenon studied, while quantitative research is characterized by the use of statistical tools in data processing, to ensure accuracy in results and avoid distortions in analysis and interpretation. The non-parametric statistical test was performed using SPSS software, version 20 .

The data collected were also processed using descriptive statistics which, according to Gil (2010), is used to describe the behavior of each variable in relation to the set of observations. The study made use of frequency calculations, to describe in percentage the level of adherence of companies in relation to each of the mandatory disclosure items, which were categorized via content analysis and spreadsheet of Microsoft Excel software.

Table 3 - Classification of Disclosure Level in Quartiles

\begin{tabular}{|c|c|c|}
\hline Quartiles & Disclosure Level & Classification \\
\hline $1^{\mathrm{o}}$ & $0 \%-25 \%$ & Bad \\
\hline $2^{\mathrm{o}}$ & $26 \%-50 \%$ & Regular \\
\hline $3^{\mathrm{o}}$ & $51 \%-75 \%$ & Good \\
\hline $4^{\mathrm{o}}$ & $76 \%-100 \%$ & Great \\
\hline
\end{tabular}

Source: Research Data

After categorizing the data and assigning scores, the disclosure level of the companies was evaluated through quartiles. These quartiles were calculated based on the possible levels of disclosure that could be presented by companies, so that each quartile has a classification level. Thus, a qualitative level of disclosure was defined for each quartile, according to Table 3.

\section{DATA ANALYSIS}

From the data collected, following the checklist of Table 1 and the categorization of Table 2, the level of disclosure of intangible assets of each company composing the study sample was presented and analyzed 
Table 4 - Intangible Assets Level of Disclosure

\begin{tabular}{|c|c|c|c|c|c|c|c|c|c|c|c|c|c|c|c|c|c|c|c|c|c|c|c|c|c|}
\hline & & \multirow[b]{3}{*}{ Total } & \multirow[b]{3}{*}{$\%$} \\
\hline & & \multicolumn{22}{|c|}{ Itens } & & \\
\hline & & 1 & 2 & 3 & 4 & 5 & 6 & 7 & 8 & 9 & 10 & 11 & 12 & 13 & 14 & 15 & 16 & 17 & 18 & 19 & 20 & 21 & 22 & & \\
\hline \multirow{19}{*}{ 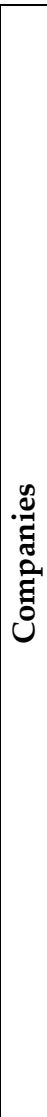 } & Ideiasnet S.A. & 3 & 0 & 3 & 3 & 3 & 0 & 2 & 0 & 0 & 0 & 0 & 3 & 0 & 3 & 3 & 3 & 3 & 0 & 0 & 0 & 0 & 0 & 29 & 43,94 \\
\hline & Linx S.A. & 3 & 0 & 3 & 3 & 2 & 3 & 2 & 0 & 0 & 0 & 0 & 3 & 0 & 3 & 3 & 3 & 3 & 0 & 0 & 0 & 0 & 3 & 34 & 51,52 \\
\hline & Quality Software S.A. & 3 & 0 & 3 & 0 & 2 & 0 & 0 & 0 & 0 & 0 & 0 & 3 & 0 & 3 & 2 & 2 & 2 & 0 & 0 & 0 & 0 & 3 & 23 & 34,85 \\
\hline & Senior Solution S.A. & 3 & 0 & 3 & 3 & 3 & 0 & 2 & 0 & 0 & 3 & 0 & 3 & 0 & 3 & 3 & 3 & 2 & 0 & 0 & 0 & 0 & 3 & 34 & 51,52 \\
\hline & $\begin{array}{l}\text { Telec Brasileiras S.A. Tele- } \\
\text { bras }\end{array}$ & 3 & 0 & 0 & 3 & 2 & 3 & 0 & 0 & 0 & 0 & 0 & 3 & 0 & 0 & 3 & 3 & 3 & 0 & 0 & 0 & 0 & 0 & 23 & 34,85 \\
\hline & Totvs S.A. & 3 & 0 & 3 & 0 & 2 & 0 & 2 & 0 & 0 & 0 & 0 & 3 & 3 & 3 & 3 & 0 & 3 & 0 & 0 & 0 & 0 & 3 & 28 & 42,42 \\
\hline & Total BM\&FBovespa (\%) & 100 & 0 & 83 & 67 & 78 & 33 & 44 & 0 & 0 & 17 & 0 & 100 & 17 & 83 & 94 & 78 & 89 & 0 & 0 & 0 & 0 & 67 & & 43,18 \\
\hline & Aconex Limited & 3 & 3 & 3 & 3 & 2 & 3 & 3 & 0 & 0 & 0 & 0 & 3 & 0 & 3 & 0 & 3 & 3 & 0 & 0 & 0 & 0 & 0 & 32 & 48,48 \\
\hline & Carsales.com Limited & 3 & 3 & 2 & 3 & 3 & 3 & 2 & 0 & 0 & 0 & 0 & 3 & 3 & 3 & 3 & 3 & 2 & 0 & 0 & 0 & 0 & 3 & 39 & 59,09 \\
\hline & Computershare Limited & 3 & 0 & 0 & 3 & 3 & 3 & 2 & 0 & 0 & 3 & 0 & 3 & 3 & 3 & 3 & 3 & 3 & 0 & 0 & 0 & 0 & 3 & 38 & 57,58 \\
\hline & $\begin{array}{l}\text { Hansen Technologies Limi- } \\
\text { ted }\end{array}$ & 3 & 0 & 3 & 3 & 3 & 3 & 3 & 0 & 0 & 0 & 0 & 3 & 3 & 3 & 3 & 3 & 3 & 0 & 0 & 0 & 0 & 3 & 39 & 59,09 \\
\hline & Iress Limited & 3 & 0 & 3 & 3 & 3 & 3 & 2 & 0 & 0 & 3 & 0 & 3 & 3 & 3 & 3 & 0 & 0 & 0 & 0 & 0 & 0 & 0 & 32 & 48,48 \\
\hline & $\begin{array}{l}\text { Link Administration Hol- } \\
\text { dings Limited }\end{array}$ & 3 & 3 & 3 & 3 & 3 & 3 & 3 & 0 & 0 & 0 & 0 & 3 & 3 & 3 & 3 & 3 & 3 & 0 & 0 & 0 & 0 & 0 & 39 & 59,09 \\
\hline & Myob Group Limited & 3 & 3 & 3 & 3 & 3 & 3 & 3 & 0 & 0 & 0 & 0 & 3 & 3 & 3 & 3 & 3 & 3 & 0 & 0 & 0 & 0 & 0 & 39 & 59,09 \\
\hline & Nextdc Limited & 3 & 3 & 2 & 3 & 3 & 3 & 3 & 0 & 0 & 0 & 0 & 3 & 0 & 3 & 0 & 0 & 0 & 0 & 0 & 0 & 0 & 0 & 26 & 39,39 \\
\hline & Technology One Limited & 3 & 0 & 2 & 3 & 3 & 3 & 2 & 0 & 0 & 0 & 0 & 3 & 0 & 3 & 3 & 3 & 3 & 0 & 0 & 0 & 0 & 0 & 31 & 46,97 \\
\hline & Xero Limited NZX & 3 & 3 & 3 & 3 & 3 & 0 & 3 & 0 & 0 & 0 & 0 & 3 & 0 & 3 & 3 & 3 & 3 & 0 & 0 & 0 & 0 & 0 & 33 & 50,00 \\
\hline & Total ASX (\%) & 100 & 60 & 80 & 100 & 97 & 90 & 87 & 0 & 0 & 20 & 0 & 100 & 60 & 100 & 80 & 80 & 77 & 0 & 0 & 0 & 0 & 30 & & 52,73 \\
\hline & Grand total (\%) & 100 & 38 & 81 & 88 & 90 & 69 & 71 & 0 & 0 & 19 & 0 & 100 & 44 & \begin{tabular}{|l|}
94 \\
\end{tabular} & 85 & 79 & 81 & 0 & 0 & 0 & 0 & 44 & & \\
\hline
\end{tabular}


As shown in Table 4, the only items that reached a level of disclosure of $100 \%$ by the sample companies were items 1 and 12. On the other hand, items 8,9,11,18, 19, 20 and 21, which correspond to $32 \%$, or approximately one-third of the 22 items in the checklist, were not disclosed by any company of the two stock exchanges. All of these items require the disclosure of information of a quantitative nature, and items 18 and 19, in addition, also require the disclosure of qualitative information. Most of these items refer to specific situations, whose applicability is restricted and conditional to the disposal of certain assets and operations carried out by the company. Because it is an information with a specific scope, the disclosure may be compromised. Therefore, there is the possibility that none of these items is applicable to the companies studied, even though there is no information in the statements and explanatory notes analyzed that supports this statement.

In the study by Lopes et al. (2014) no item reached a 100\% level of disclosure, whereas items 8,11 and 13 of that research, which correlate with items 16, 19 and 21 of the present study, were not disclosure by any company. In the study by Avelino et al. (2012) items 2 and 5, which correlate with item 5 of the present study, and item 16, which corresponds to item 15 of this research, were disclosure by all the companies analyzed, with no item that was not disclosure by at least one company analyzed. These discrepancies may be related to the fact that the studies cover distinct segments, however, can still be related to the different methods applied in the categorization of the data by the researchers.

The companies with the highest level of disclosure $(59.09 \%)$ were Carsales.com Limited, Hansen Technologies Limited, Link Administration Holdings Limited and Myob Group Limited, all Australian.Among the group of companies in Australia, the disclosure with the lowest score belongs to Nextdc Limited with 39.39\%. The highest level of disclosure among Brazilian companies was $51.52 \%$, obtained by companies Linx S.A. and Senior Solution S.A. The company with the lowest level of disclosure of the total sample belongs to the Brazilian group. The Telec Brasileiras S.A. Telebras accounted for only $34.85 \%$ of the regulatory requirements for disclosure of intangible assets. Therefore, while the highest disclosure score is from Australia, the lowest is from Brazil.

In relation to the research of Avelino et al. (2012), the maximum level of disclosure found was $88 \%$, presented by the Copel company. These results are distinct from the analyzes presented by the current research. It may be noted that the maximum level of disclosure found by the present study, both Brazilian and Australian companies, falls short of those found by the aforementioned study. It is possible to suggest that the characteristics of each sector may interfere with the disclosure made by the companies, and that the checklists used by these studies for data collection differ from those used by the present study, which can generate inconsistencies when comparing the results. The checklist used by Avelino et al. (2012) presents 17 items of analysis, and is the one closest to the checklist presented in the present study. In the study by Lopes et al. (2014), the used checklist contains 14 items, due to the fact that the study does not consider items that, according to the authors' judgment, could not be applied to all companies

Regarding the classification in quartiles, as a way of analyzing the quality of the disclosure, four companies listed on the BM\&FBovespa (67\% of Brazilian companies) obtained a regular level, while two (Linx S.A. and Senior Solution S.A.) had a good level of disclosure. In the case of companies listed on the ASX, five reached a good level of disclosure, while five achieved a level of regular disclosure, in other words, $50 \%$ in each of these quality levels. Based on these observations, it is possible to identify that no sample company, both Brazilian and Australian, obtained a level of disclosure of information on intangible assets considered excellent (above 75\%) or bad (below 25\%).

By the classification of quartiles, it can be considered that the Brazilian companies are in advantage over the Australian companies, since $67 \%$ of companies in Brazil have disclosure within the regular classification. However, Australian companies stood out from Brazilian companies regarding the general level of compliance with IAS 38 standards, as shown in Table 5. 
Table 5 - Descriptive Statistics of Levels of Evidence

\begin{tabular}{l|c|c}
\hline \multicolumn{1}{c|}{ Statistical measures } & BM\&FBovespa & ASX \\
\hline Total amount of observations & 6 & 10 \\
\hline Mean & $43.18 \%$ & $52.73 \%$ \\
\hline Median & $43.18 \%$ & $53.79 \%$ \\
\hline Mode & $51.52 \%$ & $59.09 \%$ \\
\hline Standard deviation & $7.47 \%$ & $6.99 \%$ \\
\hline Minimum & $34.85 \%$ & $39.39 \%$ \\
\hline Máximum & $51.52 \%$ & $59.09 \%$ \\
\hline
\end{tabular}

Source: Research Data

The descriptive statistics of the disclosure levels of the two stock exchanges indicates that the companies belonging to ASX had an average of disclosure of $52.73 \%$, is higher than that obtained by the companies belonging to BM\&FBovespa (43.18\%). As a result, it can be said that, on average, Australian companies have a level of compliance with IFRS, in relation to the disclosure of intangible assets, moderately higher than Brazilian companies. Comparatively, in the study by Lopes et al. (2014), the analyzed companies, which are in the industrial goods sector, obtained an average level of disclosure of $69.67 \%$.

In the study by Gallery et al. (2008) Australian companies met $47 \%$ of the criteria for disclosure of IAS 38 in 2005. Thus, it is seen that the current disclosure practiced by Australian companies is greater than at the beginning of adherence to the IFRS, indicating that the time elapsed may have been a factor that allowed companies to improve the disclosure of their information to the market. The same can not be considered for Brazilian companies.

The median of the companies listed on the BM\&FBovespa was $43.18 \%$, while the median of the companies listed on the ASX was $53.79 \%$, both very close to the average disclosure of each respective stock exchange. Regarding the variability of disclosure levels, there was a similar behavior among the companies listed on BM\&FBovespa and ASX, with standard deviations of $7.47 \%$ and $6.99 \%$, respectively. In this way, we can see that the results were very close, there is no big variation between the levels of disclosure achieved by the companies. The level of disclosure that occurred most frequently was $51.52 \%$ in the companies listed on the BM\&FBovespa and $59.09 \%$ in the case of the companies listed on the ASX, these are also the two highest levels of disclosure achieved by the companies of each respective stock exchange.

Therefore, there is in a superficial analysis, a certain proximity to the results in each country, which may be due to mimicry of what is disclosure by other companies in the same industry, causing stagnation of the quality of disclosure at the international level. In order to make a fairer comparison between the levels of disclosure of information on intangible assets between Brazilian and Australian companies, the non-parametric Mann-Whitney U test was applied, demonstrated by means of Table 6.

Table 6 - Mann-Whitney U Test of Mean difference

\begin{tabular}{l|r}
\hline Mann-Whitney U & 12,000 \\
\hline Wilcoxon W & 33,000 \\
\hline$Z$ & $-1,971$ \\
\hline Asymp. Sig. & 0,049 \\
\hline Exact Sig. & 0,056 \\
\hline \multicolumn{2}{r}{}
\end{tabular}

From the results of the Mann-Whitney U Test, it can be verified that there is statistical disclosure of difference between the means of the two groups of companies, since they presented p- 
value $=0.056$ for the $95 \%$ confidence interval. This shows that the differences in disclosure practiced by companies in the Programs and Services segment are statistically significant. This allows us to infer that Australian companies have a higher level of information disclosure than Brazilian companies, even showing the presence of a portion of asymmetric information.

These results partially fulfill the expectations of the Theory of Cultural Relevance of Accounting regarding the assumptions defended by Gray (1988) of accounting systems that approach the measurement and the disclosure, related to values (iii) and (iv). The theory indicates that the accounting developed in Brazil and Australia is surrounded by different cultural values and that this can lead to different information contexts, even if they are linked to the same international standards (Chrysostom, 2009). Therefore, through this theoretical basis, the idea that Australia can achieve greater success in complying with IFRS compared to the Brazilian case is disseminated. This perspective was answered in the present research.

However, in the Theory of Relevance of the Culture of Accounting, Brazil is framed among the countries that tend to have a moderate tendency of secrecy, while Australia belongs to the group of countries with a high degree of transparency (Gray, 1988). When comparing the theoretical expectation with the level of disclosure found by the current research, there is a possible discrepancy. Being Australia's average disclosure score of $52.73 \%$, it can not be classified as highly transparent, since it met slightly more than half of the normative criteria. This perception may reflect a shift in the cultural values of countries in view of the time elapsed between Hofstede's (1980) research and the present study. But it also shows that Australia still maintains the superior trend of disclosing information to stakeholders through accounting.

This perception is consistent with the conclusion of the study by Costa et al. (2016), which found levels of close disclosure of contingent liabilities in Brazilian and Australian companies, but that Australian companies were also among the companies that published more information. These authors also agreed that the cultural differentiation between Brazil and Australia is a relevant factor in the way accounting is developed in each country.

Comparing the results found with the cultural aspects presented by Kushniroff (2012), Souza (2009) and Chrysostom (2009) it is noted that the results are in accordance with the cultural assessment presented, given the greater tendency of Australians to disclose relevant information to the users of the accounting information, due to the lower level of secrecy presented. Conversely, the high level of secrecy presented by Brazilians may represent a barrier to disclosure of information and adherence to IFRS.

\section{CONCLUSION}

The present study aimed to evaluate the differences in the disclosure practices of intangible assets, according to IFRS specifications, in Brazilian and Australian companies. To this end, the analysis focused on companies in the information technology sector, Program and Services sub-sector (Software \& Services), listed on BM\&FBovespa and the Australian Securities Exchange. The analysis used data from the financial statements for the year ended in 2015 of sixteen companies, with six of them listed on the Brazilian stock exchange (BM\&FBovespa) and ten of them listed on the Australian stock exchange (Australian Securities Exchange).

From the presented results it was verified that there are differences in the adhesion to IAS 38 by Brazilian and Australian companies. The slightly better result of Australian companies is supposedly related to the longer time to comply with IFRSs. While Australia has already adopted them since 2005, Brazil only began to adopt them, in a mandatory way, as of 2010, in other words, there is a five-year lag that could contribute to greater adaptability in meeting standards. This perception can be verified regarding the level of disclosure of intangible assets of Australian companies, which, 
nowadays, is superior in relation to the research done by Gallery et al. (2008) in the period of adoption of AASB 138.

However, the different cultural aspects between countries may explain the results found. As advocated by Gray's Theory of Relevance in the Culture of Accounting (1988), Australian accountants are more likely to disclose information to users of financial statements compared to Brazilians. Australia, belonging to the group of countries of Anglo-Saxon origin and indicated with the trend of information disclosure, met the theoretical precepts. This is why the average compliance rate of the Australian companies' normative criteria evaluated by this study was higher than the average rate of the Brazilian companies present in the sample.

However, part of the theory does not apply to the results found, since Gray (1988) ranks Australia in the set of countries with a culture focused on the wide dissemination of accounting information and Brazil tied to the value of secrecy. Considering the small margin of difference in the mean scores between the two groups of companies, it can be verified that the theory proposed by Gray (1988) is based on mutable social factors, and that, therefore, the supposed tendencies of the actions of the accounting agents reported by this theory need to be reviewed.

This possibility is reinforced by the fact that the propensity of companies from both to meet or not the normative criteria are similar. From this perspective, the opportunity arises to discuss adherence to the IFRS regarding non-compliance with certain normative criteria and the relationship between local culture and disclosure. In other words, to investigate possible determinants of nondisclosure of information emerging from the local culture and possible ways of minimizing it, since the current academic discussions should rest on the absence, not the compliance of accounting with disclosure norms, since this is already expected and obligatory.

It is necessary to investigate in greater depth, specifically, information that is not disclosed, not only on the intangible asset, but also about all the others accounting standards. This means compiling all research on disclosure and analyzing the characteristics of information that is not usually disclosed.

The other discussion that emerges is about the relationship between the culture of each country and the normative requirements. Whereas it is expected that all countries will need to develop globally standard accounting, the local culture can be a factor that partially justifies the informational asymmetry practiced by the companies.

When considering only the local culture, and knowing that Brazil is among a group of countries that is resistant to divulging information about the financial and economic conditions of the companies to the market, it is possible to glimpse a possible future scenario. Even with the adoption of internationally standardized accounting standards, Brazil as well as other countries with similar cultural characteristics, tends to be at a lower level than countries with cultures that welcome the practice of disclosure. This means that the Brazilian capital market may be adversely affected, especially as regards the attraction of foreign investments, as an important element for the development of the Brazilian economy. This is because investors may prefer investments in countries with higher transparency rates, which contributes to the construction of more reliable estimates of the expected return.

Therefore, it raises the question about the position of the Brazilian institutions that emit accounting standards, such as the CVM and the CPC, on actions taken to adapt Brazilian trends from the culture in order to meet the information needs of the market, as required by IFRS. After the period of adaptation to international accounting standards, and seeing greater stability in accounting performance, it is up to the institutions to develop resources that influence companies and accountants to understand the relevance of disclosure. The education carried out by universities shows itself as an important channel for adapting the accounting culture established in Brazil. 
The perception defended by the present study broadens the understanding that the behavioral aspect established in a country through its culture plays an important role in the actions practiced individually. This can not be disregarded, as there is the same requirement for accounting practices anywhere in the world. Based on this, the understanding of accounting from behavioral and local precepts is a way to be explored by surveys. The findings of the present study showed of the opening of this possibility and a motivator in the continuity of such investigations.

Regarding the limitations of the study, it should be noted that due to the small number of companies surveyed and the fact that only a part of the information technology sector has been addressed, the results obtained by the research can not be generalized. It also configures the researcher's judgment as a limitation of the study during the framework according to the proposed categorization and the difficulty in comparing current results with previous research in view of the methods applied in data collection and analysis. It is suggested for future research to use data from financial statements of the following exercises with an expanded sample and to use the same methodological aspects to verify the influence of time in adherence to international accounting standards. It is also suggested to reapply this research with data from more countries, in order to contribute to the consolidation of the Theory of Relevance of the Culture of Accounting through a broader empirical.

\section{REFERENCES}

Australian Accounting Standards Board (2014). AASB 138 Intangible Assets. Amended by AASB 20144. 2014. Retrieved May 10, 2016 from the World Wide Web: http://www.aasb.gov.au/.

Avelino, B. C., Pinheiro, L. E. T. \& Lamounier, W. M. (2012). Evidenciação de ativos intangíveis: estudo empírico em companhias abertas. Revista de Contabilidade e Organizações, 6(14), p. 2345.

Bardin, L. (1977). Análise de Conteúdo. Lisboa: Edições 70.

Belém, V. C., \& Marques, M. M. (2012). A influência dos ativos intangíveis na rentabilidade do patrimônio líquido das empresas brasileiras. Anais do Congresso USP de Controladoria e Contabilidade, São Paulo, SP, Brasil, 12.

Beuren, I. M., Longaray, A. A., Raupp; F. M., Sousa; M. A. B.; Colauto, R. D. \& Porton, R. A. B. (2006). Como elaborar trabalhos monográficos em contabilidade: teoria e prática. (3. ed.). São Paulo: Atlas.

Colauto, R. D., Nascimento, P. S., Avelino, B. C. \& Bispo, O. N. A. (2009). Evidenciação de Ativos Intangíveis Não Adquiridos nos Relatórios da Administração das Companhias Listadas nos Níveis de Governança Corporativa da Bovespa. Revista Contabilidade Vista \& Revista, 20(1), p. 142-169.

Costa, I. L. S., Correia, T. S., Machado, M. R., \& Lucena, W. G. L. (2016). Disclosure dos Passivos Contingentes: Análise Comparativa entre Empresas de Mercado Aberto no Brasil e Austrália. Anais do Seminário UFPE de Ciências Contábeis, Recife, PE, Brasil, 10.

Comitê de Pronunciamentos Contábeis. (2010). Pronunciamento técnico CPC 04 R1 - Ativos Intangíveis. 2010. Retrieved May 10, 2016 from the World Wide Web: http://www.cpc.org.br.

Comissão de Valores Mobiliários. (2007). Instrução Normativa no 457, de 13 de julho de 2007. Dispõe sobre a elaboração e divulgação das demonstrações financeiras consolidadas, com base no padrão contábil internacional emitido pelo International Accounting Standards Board - IASB. Retrieved May 28, 2016 from the World Wide Web: http://www.cvm.gov.br.

Crisóstomo, V. L. (2009). Ativos Intangíveis: estudo comparativo dos critérios de reconhecimento, mensuração e evidenciação adotados no Brasil e em outros países. Contabilidade, Gestão e Governança, 12(1), p. 50-68. 
Dantas, J. A., Zendersky, H. C., Santos, S. C. D., \& Niyama, J. K. (2005). A dualidade entre os benefícios do disclosure e a relutância das organizações em aumentar o grau de evidenciação. $E \mathcal{E}$ G Economia e Gestão, 5(11), p. 56-76.

Gallery, G., Cooper, E., \& Sweeting, J. (2008). Corporate Disclosure Quality: Lessons from Australian Companies on the Impact of Adopting International Financial Reporting Standards. Australian Accounting Review, 18(46), p. 257-273.

Gil, A. C. (2010). Como elaborar projetos de pesquisa. (5. ed.). São Paulo: Atlas.

Gray, S. J. (1988). Towards a Theory of Cultural Influence on the Development of Accounting Systems Internationally. Abacus, 24(1), p. 1-15.

Hofstede, G. (1980). Culture's Consequences: International Differences in Work-Related Values. Beverly Hills, CA: Sage.

International Accounting Standards Board. (2013). IAS 38 Intangible Assets. Amended by Annual Improvements to IFRSs 2010-2012 Cycle. Retrieved May 10, 2016 from the World Wide Web: http://eifrs.ifrs.org/eifrs/bnstandards/en/2016/ias38.pdf.

Klann, R. C, Popik, F., Kreuzberg, F., \& Salla, N. G. (2014). Fatores Relacionados ao Nível de Divulgação de Ativos Intangíveis após a Adoção das IFRS por Empresas do IGC da BM\&FBOVESPA. Revista Catarinense da Ciência Contábil, 13(38), p. 37-51.

Kushniroff, M. C. (2012). An Analysis of the Obstacles of Culture, Government, and Lack of Support for International Financial Accounting Standards. Academy of Accounting and Financial Studies Journal, 16, p. 35-54.

Lima. B. J. (2016). O Impacto das Dimensões Culturais sobre a Prática Contábil no Brasil: um olhar a partir da Percepção dos Operadores da Contabilidade. Revista de Educação e Pesquisa em Contabilidade, 10(4), p. 363-379.

Lopes, L. C., Alves, N. M., Silva Filho, L. L., Monteiro, J. A. M., Lagioia, U. C. T., \& Cordeiro, P. C. (2014). Evidenciação das Informações dos Ativos Intangíveis: Um Estudo Sobre o Nível de Aderência das Companhias Brasileiras do Setor de Bens Industriais Listadas na Bolsa de Valores do Brasil ao CPC 04. Qualitas Revista Eletrônica, 15(1), p. 1-14.

Martins, G. A., \& Theóphilo, C. R. (2009). Metodologia da investigação científica para ciências sociais aplicadas. (2. ed.). São Paulo: Atlas.

Meneses, A. F., Ponte, V. M. R., \& Mapurunga, P. V. R. (2013). Determinantes do Nível de Disclosure de Ativos Intangíveis em Empresas Brasileiras. BASE - Revista de Administração e Contabilidade da Unisinos, 10(2). p. 142-153.

Moura, G. D., Dallabona, L. F., Fank, O. L., \& Varela, P. S. (2013). Relação entre ativos intangíveis e governança corporativa. Revista Contabilidade e Controladoria, 5(1), p. 120-138.

Oliveira, V. A., \& Lemes, S. (2011). Nível de convergência dos princípios contábeis brasileiros e norte-americanos às normas do IASB: uma contribuição para a adoção das IFRS por empresas brasileiras. Revista Contabilidade E Finanças, 22(56), p. 155-173.

Silva, A. C. R. (2010). Metodologia da pesquisa aplicada à contabilidade. (3. ed.). São Paulo: Atlas.

Souza, R. G. (2009). Normas internacionais de contabilidade: percepções dos profissionais quanto às barreiras para sua adoção no Brasil. Dissertação (Mestrado em Administração) - Escola de Administração de Empresas de São Paulo, Fundação Getúlio Vargas. São Paulo. 